

\section{Daftar Isi (Table of Content) Journal of Government
Civil Society}

\begin{tabular}{|c|c|}
\hline \multirow{3}{*}{$1-34$} & $\begin{array}{l}\text { Akuntabilitas Politik dalam Anggaran (Studi Kasus: Dana Gerakan Dusun } \\
\text { Membangun (GDM) di Kabupaten Bungo) }\end{array}$ \\
\hline & Fajar Trilaksana Moedarlis \\
\hline & (Magister Ilmu Pemerintahan, Universitas Muhammadiyah Yogyakarta, Indonesia) \\
\hline \multirow[b]{3}{*}{$35-46$} & $\begin{array}{l}\text { Civil Servants Performance Analysis of Education, Youth and Sports } \\
\text { Department in Bantul District } 2017\end{array}$ \\
\hline & Surya Jaya Abadi ${ }^{1}$, Muhammad Eko Atmojo ${ }^{2}$, Helen Dian Fridayani ${ }^{3}$ \\
\hline & $\begin{array}{l}\left({ }^{1} \text { Government Affairs and Administration, Universitas Muhammadiyah Yogyakarta, }\right. \\
\text { Indonesia) } \\
\left({ }^{2} \text { Government Affairs and Administration, Universitas Muhammadiyah Yogyakarta, }\right. \\
\text { Indonesia) } \\
\left({ }^{3} \text { Government Affairs and Administration, Universitas Muhammadiyah Yogyakarta, }\right. \\
\text { Indonesia) }\end{array}$ \\
\hline \multirow{3}{*}{$47-61$} & $\begin{array}{l}\text { Efektivitas Pengawasan Badan Pengawas Obat dan Makanan (BPOM) } \\
\text { terhadap Peredaran Makanan Impor oleh Pedagang UMKM di Kota } \\
\text { Pekanbaru }\end{array}$ \\
\hline & Ferry Angriawan ${ }^{1}$, Dyah Mutiarin ${ }^{2}$ \\
\hline & $\begin{array}{l}\text { ('Magister Ilmu Pemerintahan, Universitas Muhammadiyah Yogyakarta, Indonesia) } \\
\text { ('Magister Ilmu Pemerintahan, Universitas Muhammadiyah Yogyakarta, Indonesia) }\end{array}$ \\
\hline \multirow{3}{*}{$63-78$} & $\begin{array}{l}\text { Institusionalisasi Partai Politik dalam Pilkada } 2017 \text { (Studi Kasus: Partai } \\
\text { Golkar Provinsi Kepulauan Bangka Belitung) }\end{array}$ \\
\hline & Agam Primadi', Titin Purwaningsih ${ }^{2}$ \\
\hline & $\begin{array}{l}\left({ }^{1} \text { Magister Ilmu Pemerintahan, Universitas Muhammadiyah Yogyakarta, Indonesia) }\right. \\
\left({ }^{2} \text { Magister Ilmu Pemerintahan, Universitas Muhammadiyah Yogyakarta, Indonesia) }\right.\end{array}$ \\
\hline \multirow[b]{3}{*}{$79-91$} & $\begin{array}{l}\text { Public Value in Clean Water Management at the Local Water Supply Utility } \\
\text { (PDAM) Tirta Kerta Raharja (TKR) }\end{array}$ \\
\hline & Arsid1', Ida Widianingsih², Heru Nurasa ${ }^{3}$, Entang Adhy Muhtar ${ }^{4}$ \\
\hline & $\begin{array}{l}\left({ }^{1} \text { Mahasiswa Program Pascasarjana Administrasi Publik, FISIP Universitas Padjadjaran, }\right. \\
\text { Indonesia) } \\
\text { ('Pusat Studi Desentralisasi dan Pembangunan Partisipatif, FISIP Universitas } \\
\text { Padjadjaran, Indonesia) } \\
\text { ('Departemen Administrasi Publik, FISIP Universitas Padjadjaran, Indonesia) } \\
\left({ }^{4} \text { Departemen Administrasi Publik, FISIP Universitas Padjadjaran, Indonesia) }\right.\end{array}$ \\
\hline
\end{tabular}




\title{
Institusionalisasi Partai Politik dalam Pilkada 2017 (Studi Kasus: Partai Golkar Provinsi Kepulauan Bangka Belitung)
}

\author{
Agam Primadi ${ }^{1}$, Titin Purwaningsih ${ }^{2}$ \\ ${ }^{1}$ Magister Ilmu Pemerintahan, Universitas Muhammadiyah Yogyakarta, Indonesia \\ Email: agamprimadi08@gmail.com \\ ${ }^{2}$ Magister Ilmu Pemerintahan, Universitas Muhammadiyah Yogyakarta, Indonesia \\ Email: titin.p.widodo@gmail.com
}

\begin{abstract}
ABSTRAK
Kontestasi politik di tingkat daerah Provinsi Kepulauan Bangka Belitung menghasilkan dimanika politik yang dinamis, salah satunya adalah perolehan suara Partai Golkar pasang surut. Hal ini berdampak terhadap perolehan suara pesta demokrasi yang terlaksana di lingkungan Provinsi Kepulauan Bangka Belitung. Secara spesifik, penelitian ini bertujuan menganalisis pelembagaan Partai Golkar Provinsi Kepulauan Bangka Belitung pascakekalahan di pemilihan Gubernur tahun 2017. Selain itu, penelitian ini berupaya melihat carut-marutnya proses rekrutmen politik di internal partai. Penelitian ini mengunakan metode kualitatif dengan teknik pengumpulan data wawancara, observasi, serta pemanfaatan data sekunder dan primer. Kekalahan calon dari Partai Golkar disebabkan institusionalisasi partai politik di internal Partai Golkar Provinsi Kepulauan Bangka Belitung belum berjalan maksimal dan baik. Selain itu, ada juga beberapa faktor lainnya. Pertama, pengambilan kebijakan rekrutmen calon Gubernur dan Wakil Gubernur pada pemilihan tahun 2017 masih diwarnai dengan pelanggaran konstitusi partai dalam arti proses rekrutmen tidak dilakukan berdasarkan mekanisme aturan AD/ART partai. Pengurus Golkar di level daerah tidak dilibatkan dalam proses penjaringan, seleksi, dan penetapan calon Gubernur di tubuh partai Golkar. Kedua, adanya " politik dagang sapi" dalam proses rekrutmen mengisyaratkan kecendrungan uang masih sangat kuat dalam mendapatkan rekomendasi dari level pusat dan dukungan dari level pengurus partai di daerah.
\end{abstract}

Kata Kunci: Institusionalisasi partai politik, oligarki politik, elit politik, Partai Golkar.

\begin{abstract}
Political contestation in Bangka Belitung Province produces a dynamic political situation, one of which is the vote acquisition of the ups and downs of the Golkar Party. This has an impact on the vote acquisition of democratic parties carried out in Bangka Belitung Province. Specifically, this study aims to analyze the institutionalization of the Golkar Party in the Province of Bangka Belitung in the aftermath of the Governor's election in 2017. In addition, this study seeks to see the chaotic process political parties recruitment within the party. This research uses qualitative methods with techniques for collecting data on interviews, observations, and the use of secondary and primary data. The defeat of Golkar Party candidates is due to the institutionalization of political parties internally in the Golkar Party that has not run optimally and good. In addition, there are also several other factors. First, the recruitment of the Governor and Deputy Governor candidates' recruitment policy in the 2017 election is still tinged with violations of the party's constitution in sense that the recruitment process is not based on the mechanism of the party's AD/ART. The Golkar Party administrators at the regional level were not involved in the selection and determination of governor candidates. Secondly, the existence of "politik dagang sapi" in the recruitment process suggests that the money tendency is still very strong in getting recommendations from the central level and support from the level of party managers in the region.
\end{abstract}

Keywords: Institutionalization of political parties, political oligarchs, political elites, Golkar Party

Citation : Primadi, Agam dan Titin Purwaningsih. 2019. "Institusionalisasi Partai Politik dalam Pilkada 2017 (Studi Kasus: Partai Golkar Provinsi Kepulauan Bangka Belitung)". Journal of Government and Civil Society, Vol. 3, No. 1, 63-78. 


\section{PENDAHULUAN}

Kehadiran partai politik secara resmi berawal dari maklumat 3 November Tahun 1945 Tentang Pembentukan Partai Politik yang dikeluarkan oleh Wakil Presiden Drs. Moh. Hatta. Lahirnya berbagai macam partai politik menjadi awal perkembangan demokrasi di Indonesia, karena partai politik adalah salah satu syarat berjalannya sistem pemerintahan yang demokratis. Diawal pembentukannya ini, jumlah partai politik di Indonesia sangat banyak dan tergolong pada sistem kepartaian multipartai.Sebuah partai politik adalah organisasi politik yang menjalani ideologi tertentu atau dibentuk dengan tujuan khusus. Definisi lainnya adalah kelompok yang terorganisir yang anggotaanggotanya mempunyai orientasi, nilai-nilai, dan cita-cita yang sama(Towar Ikbal Tawakkal, 2009).

Dimasa orde baru (ORBA) mengalami perubahan, terjadi pemangkasan sehingga hanya ada dua partai politik yakni Partai Demokrasi Indonesia dan Partai Persatuan Pembangunan. Selain kedua partai tersebut, muncul organisasi yang berperan sangat aktif dalam perpolitikan saat itu yakni Organisasi Kekaryaan atau Golongan Karya. Keberadaan dan eksistensi organisasi ini dalam proses demokrasi masa Orde Baru dilegalkan melalui UU No. 3 Tahun 1975 Tentang Partai Politik dan Golongan Karya, sehingga pemerintah hanya mengakui dua buah partai politik yakni Partai Persatuan Pembangunan (PPP) dan Partai Demokrasi Indonesia (PDI) serta satu Organisasi Sosial yakni Golongan Karya. Organisasi Golongan Karya kemudian menjadi sangat eksis dalam berbagai kegiatan kenegaraan kemudian berevolusi menjadi sebuah partai di Indonesia.

Melalui Peraturan Presiden (Perpres) No. 193/1964 yang dikeluarkan Presiden Soekarno, Partai Golkar lahir dan berkiprah di Nasional dengan dibekali pelembagaan partai yang matang. Kehadiran partai Golkar memunculkan dinamika baru dikancah perpolitikan. Eksistensi partai Golkar berhasil menjadi salah satu partai dengan perolehan suara yang signifikan. Meski demikian, kejayaan Partai Golkar mengalami kemunduran yang ditandai dengan menurunnya perolehan suara partai di tingkat nasional pada pemilu legislatif tahun 1999.

Pada pemilu legislatif tahun 1999, Partai Golkar menduduki posisi kedua dalam perolehan suara nasional dengan perolehan 23.741 .758 suara atau 22,44\% dari suara sah atau mengalami penurunan sebesar 0,86 dibanding pemilu legislatif tahun 1997. Penurunan elektabilitas Partai Golkar di era reformasi pada kenyataannya tidak sama dengan asumsi sejumlah orang yang menganggap bahwa reformasi 1998 akan melumpuhkan Partai Golkar secara struktural hingga level akar rumput. Faktanya, Selama pemilu tahun 1999, 2004, dan 2009 perolehan suara Partai Golkar masih tinggi dalam perhitungan nasional. (Holil, 2009:42).Perolehan ini tidak terlepas dari keutuhan perolehan suara, baik di tingkat Provinsi maupun Kabupaten/Kota, yang secara substansial menyumbang perolehan suara di tingkat nasional. (Tanjung, 2007: 64). 
Hal demikian juga terjadi di Provinsi Kepulauan Bangka Belitung. Partai Golkar Provinsi Kepulauan Bangka Belitung lahir seiring dengan terbentuknya Provinsi pada tahun 2000. Pimilihan legislatif 2009 mengalami penurunan meskipun tidak signifikan. Dominasi Partai Golkar di legislatif mematahkan stigma miring terhadap indikasi penurunan elektabilitas dan perolehan suara. Berikut hasil pileg 2009 terinci dalam Tabel 1. berikut.

Tabel 1. Perolehan Suara / Kursi Parpol Pemilu 2009 Provinsi Kepulauan Bangka Belitung

\begin{tabular}{clcc}
\hline No & Nama Partai Politik & Perolehan Suara & Perolehan Kursi \\
\hline 1 & Partai Hati Nurani Rakyat & 21.661 Suara & 3 Kursi \\
2 & Parti Gerakan Indonesia Raya & 21.707 Suara & 2 Kursi \\
3 & Partai Keadilan Sejahtera & 42.320 Suara & 5 Kursi \\
4 & Partai Amanat Nasional & 26.579 Suara & 3 Kursi \\
5 & Partai Golongan Karya & 71.995 Suara & 7 Kursi \\
6 & Partai Persatuan Pembangunan & 37.967 Suara & 7 Kursi \\
7 & Partai Bulan Bintang & 33.060 Suara & 3 Kursi \\
8 & Partai Demokrasi Indonesia & 88.141 Suara & 8 Kursi \\
& Perjuangan & & \\
9 & Partai Demokrat & 47.381 Suara & 7 Kursi \\
& Jumlah & 464.240 Suara & 45 Kursi \\
\hline
\end{tabular}

Sumber : KPU Provinsi Kepulauan Bangka Belitung.

\section{KERANGKA TEORI}

\section{Institusionalisasi Partai Politik}

Parpol menjadi jembatan penghubung politis antara pemilik kekuasaan, yaitu rakyat, dengan pemerintah sebagai pemegang mandat kekuasaan. Selain itu fungsinya juga menjadi sentral dalam sebuah negara demokrasi. (Harjanto, 2011). Perubahan penting yang dialami Indonesia dalam menjalankan proses demokratisasi antara lain munculnya berbagai macam partai politik. Di era reformasi setelah dibukanya kebebasan mendirikan partai politik, nuansa politk bangsa sangat disesaki oleh aktivitas partai politik (Solikhin, 2017). Sebagai tuntutan organisasi yang modern partai politik dituntut untuk memiliki etika kepemimpinan yang demokratis dan kolegial, etika organisasi, dan etika pertanggungjawaban kepada masyarakat yang semuanya dilembagakan dalam mekanisme internal partai yang disepakati bersama (Syamsuddin, 2016). 
Pelembagaan partai politik adalah proses dalam pemantapan sikap dan perilaku partai politik yang sistematik dan terpola dalam mendukung prinsip dasar demokrasi (Imansyah, 2012). Netherlands Institute for Multiparty Democracy (IMD) melihat pelembagaan berdasarkan demokrasi internal, keutuhan internal, identitaspolitik berkaitan dengan ideologi partai, ketangguhan organisasi dan kapasitas berkampanye(Romli, 2016). teori pelembagaan partai politik Vicky Randall dan Lars Svasand (2002), dimana dalam tulisannya Randall dan Svasand membagi tingkat pelembagaan partai politik menjadi empat dimensi. Yang pertama yaitu dimensi kesisteman (sistemness), kedua dimensi identitas nilai (value infusion), ketiga dimensi otonomi suatu partai dalam pembuatan keputusan (decisional autonomy), dan keempat dimensipengetahuan atau citra publik (reification)(Eristyawan, 2014).

Menurut Huntington (1968:12), institusionalisasi partai politik adalah sebuah proses pengorganisasian dan prosedur untuk mendapatkan value (nilai) dan stability (stabilitas) tertentu. Ketika partai politik telah berhasil memformulasi dan menginternalisasi nilainilai organisasionalnya serta dalam periode waktu tertentu terdapat stabilitas internal, maka partai politik tersebut dapat dikatakan telah terlembagakan dengan baik.

Samuel P. Huntington, dalam buknya "Political Order In Changing Societies" memaknai pelembagaan (lembaga politik) sebagai proses dengan mana organisasi dan tata cara memperoleh nilai baku dan stabil. Tingkat pelembagaan setiap sistem politik dapat ditentukan dari segi kemampuan untuk menyesuaikan diri, kompleksitas, otonomi dan keterpaduan. Selain itu, pelembagaan dapat diukur dari ukuran ukuran ; pertama, penyesuaian diri, kedua, kekakuan, ketiga, kompleksitas, keempat kesederharnaan, kelima, otonomi-subordinasi, dan keenam, persatuan-perpecahan. Gagasan utama tentang konteks pelembagaan partai politik dalam sistem politik untuk menyumbang terciptanya political order yang dapat digunakan sebagai kerangka analisis adalah seperti pada tabel sebagai berikut : 
Tabel 2. Analisis Pelembagaan Partai Politik

\begin{tabular}{|c|c|}
\hline Gagasan Utama & Samuel P.Huntington \\
\hline Konteks Pelembagaan Partai & 1. Tertib politik \\
\hline \multirow[t]{3}{*}{ Politik } & 2. Sistem politik \\
\hline & 3. Stabilitas politik \\
\hline & 4. Partisipasi politik \\
\hline \multirow[t]{2}{*}{ Pelembagaan Partai Politik } & 1. Nilai baku \\
\hline & 2. Stabil \\
\hline Parameter Pelembagaan Partai & Kemampuan partai politik: \\
\hline \multirow[t]{4}{*}{ Politik } & $\begin{array}{l}\text { 1. Menyesuaikan diri (usia organisasi, usia } \\
\text { generasi, fungsi) }\end{array}$ \\
\hline & 2. Kompleksitas \\
\hline & 3. Otonomi \\
\hline & 4. Keterpaduan organisasi dan tata cara \\
\hline \multirow[t]{4}{*}{$\begin{array}{l}\text { Implikasi parameter } \\
\text { pelembagaan partai politik }\end{array}$} & $\begin{array}{l}\text { 1. Kemampuan menyesuaikan diri } \\
\text { terhadap peruabahan (tidak sebatas } \\
\text { melaksanakan fungsi partai) }\end{array}$ \\
\hline & $\begin{array}{l}\text { 2. Diferesiasi sub-unit organisasi (hirarki- } \\
\text { fungsional) }\end{array}$ \\
\hline & $\begin{array}{l}\text { 3. Tidak tergantung dari organisasi politik } \\
\text { dan metode perilaku yang lain }\end{array}$ \\
\hline & 4. Keutuhan organisasi \\
\hline \multirow[t]{3}{*}{$\begin{array}{l}\text { Efek implikasi parameter } \\
\text { pelembagaan partai politik }\end{array}$} & $\begin{array}{l}\text { 1. Kemampuan partai dalam mengelola } \\
\text { organisasi internal (stabilitas internal, } \\
\text { demokrasi internal, konsensus) }\end{array}$ \\
\hline & 2. Hubungan antar-partai \\
\hline & 3. Peran dalam sistem politik \\
\hline
\end{tabular}

Sumber : Huntington, Political Order in Changing Societies

Sedangkan menurut Basedau dan Stroh (2008) ada empat dimensi pelembagaan partai, jika di uraikan adalah sebagai berikut: Pertama, Roots in society ( mengakar dalam masyarakat), maksudnya adalah partai ini memiliki akar yang stabil dalam masyarakat. Kedua, autonomy (independen dalam mengambil keputusan), maksudnya adalah kebebasan partai politik dari pengaruh luar partai dalam mengambil setiap keputusan dan kebijakan partai. Ketiga, level of organization ( alat organisasi yang selalu bekerja untuk kepentingan partai di setiap tingkat kepengurusan), maksudnya adalah kepengurusan ditingkat atas hingga kepengurusan di tingkat bawahnya bekerja untuk kepentingan partai guna membesarkan partai dan memberikan kemenangan dalam pemilu. Keempat, coherence (kekompakan para anggota partai), maksudnya adalah 
kekompakan anggota partai dalam parlemen, sehingga tidak terjadi pembelotan dari anggota partai dan tetap berpegang teguh pada kebijakan partai yang telah diambil.

Tabel 3. Pelembagaan Partai Politik

\begin{tabular}{ccc}
\hline & Stability & Value Infusion \\
\hline External & Roots in society & Autonomy \\
Internal & Level of organization & Coherence \\
\hline
\end{tabular}

Sumber : Basedau dan Stroh (2008)

Empat dimensi pelembagaan partai politik tersebut, terdapat indikator untuk mengukur pelembagaan partai politik. Sehingga dalam penelitian ini, teori yang digunakan peneliti adalah teori institusionalisasi menurut Basedau dan Stroh. Partai Golkar Bangka Belitung telah beberapa kali mengikuti pemilu, serta perolehan suara kursi di DPRD Provinsi Kepulauan Bangka Belitung pada pileg 2014 cukup stabil, hal ini juga demikian terjadi di Pileg 2009, Partai Golkar meraih 7 Kursi di DPRD Provinsi Kepulauan Bangka Belitung.

Partai Golkar Provinsi Kepulauan Bangka Belitung juga telah mengalami pergantian ketua sebanyak 4 kali sejak Provinsi Kepulauan Bangka Belitung terbentuk. Hal ini menunjukkan bahwa terjadi dinamika yang sangat menarik di internal partai. Fenomena serta kondisi partai Golkar Provinsi Kepulauan Bangka Belitung tersebut tentunya akan sangat relevan jika di analisis melalui indikator pelembagaan partai politik menurut Basedau dan Stroh.

\section{Oligarki Politik}

Sejarah oligarki merupakan sejarah yang identik dengan dua hal, pertama oligarki menandaskan superioritas orang berpunya, kedua oligarki identik dengan bagaimana sepak terjang mereka di dunia politik dalam posisinya sebagai elit. Dalam perkembangannya, teorisasi soal oligarki dalam kacamata ekonomi politik perlahan-lahan mulai bias dan bercampur aduk dengan teori elit. (Winters, 2011:40).

Sumber daya kekuasaan sebagaimana yang diklasifikasikan oleh Winters, memiliki relevansi kuat pada corak aktor yang menggunakannya. Sumber daya kekuasaan ini terbagi ke dalam lima jenis. Pertama adalah hak politik formal, kedua, jabatan resmi, ketiga adalah kekuasaan koersi (pemaksaan), keempat adalah kekuasaan mobilisasi, dan terakhir adalah basis kekuatan material. Empat sumber daya kekuasaan yang disebutkan di awal merupakan kombinasi akumulasi yang membentuk kekuatan elit. Sedangkan sumber yang terakhir merupakan basis terpenting eksistensi oligark. 
Dalam konteks demokrasi, keterlibatan oligark dalam politik praktis melalui Pemilu juga menarik untuk ditelaah meskipun oligarki dengan demokrasi sangat berbeda. Di mana oligark meletakkan konsentrasi kekuasaan pada kekayaan (klaim terhadap kepemilikan dan kekayaan), sedangkan demokrasi meletakkan konsentrasi pada persebaran kekeuasaan non- material (hak, prosedur, dan tingkat partisipasi). Winters (2011) menjelaskan tentang sumber daya kekuasaan yang menurutnya ada lima bentuk kekuasaan individu yang penting, yaitu :

1. Kekuasaan berdasarkan hak politik formal;

2. Jabatan resmi dalam pemerintah atau organisasi;

3. Kekuasaan pemaksaan/koersif;

4. Kekuasaan mobilisasi;

5. Kekuasaan material.

Sedangkan dalam konteks Pilkada, apabila elit politik memiliki kelima sumber kekuasaan tersebut, maka ia dapat berbuat apapun untuk mencapai tujuan politiknya. Lebih jauh, dari pandangan tersebut dapat dijelaskan bahwa munculnya calon tunggal pada pemilukada Kabupaten Landak dan beberapa daerah lainnya dikarenakan terdpaat oligarki di tubuh partai politik karena para elit memiliki 5 (lima) sumber kekuasaan sebagaimana yang dikemukakan oleh Winters. Tidak hanya memiliki kekuasaan, tetapi mereka juga memiliki sumber daya yang maksimal untuk memobilisasi massa guna memperoleh dukungan politik.

Winters (2011) dalam studinya, membagi oligarki dalam beberapa tipe, antara lain:

1. Oligakri panglima (Warring Oligarchy)

2. Oligarki penguasa kolektif (Ruling oligarchy)

3. Oligarki Sultanistik (Sultanistik Oligarchy)

4. Oligarki Sipil (civil oligarchy)

Teori oligarki dapat digunakan untuk menjelaskan mengenai kekuatan finansial yang menjadi salah satu kekuatan Hidayat Arsani untuk dapat mendapatkan rekomendasi dari partai politik sebgai kendaraan untuk maju dalam pesta demokrasi pada tahun 2017 di Provinsi Kepulauan Bangka Belitung. Kekuatan uang menjadi pengaruh terkuat dalam mendapatkan rekomendasi tersebut. 


\section{Elit Politik}

Kata elit dapat diartikan dalam berbagai konteks yang berarti terbaik, istimewa, paling mulia atau hal yang terbaik dari sesamanya. Pereto (dalam Varma,1975) menjelaskan bahwa elit secara sederhana dapat diartikan sebagai individu yang memiliki kemampuan istimewa atau lebih dalam kegiatan tertentu seperti pengetahuan politik atau bisnis besar. Pareto juga membagi istilah elit kedalam dua hal. Pertama, a governing elite yaitu sekumpulan pemimpin yang secara langsung maupun tidak langsung memiliki peran dalam mengatur masyarakat. Kedua, a non-governing elite yaitu sebagai pengingat atau pengkritik dari kelompok elit itu sendiri. Dalam pengetahuan sosial kontemporer, kata elit mengacu pada kelompok-kelompok yang memiliki status tinggi dalam masyarakat karena alasan apapun. (Patrick dan Brendan 1987).

Elite non politik ini seperti: elite keagamaan, elit organisasi kemasyarakatan, kepemudaan, profesi dan lain sebagainya. Perbedaan tipe elite lokal ini diharapkan selain dapat membedakan ruang lingkup mereka, juga dapat memberikan penjelasan mengenai hubungan antar-elite politik maupun elite mesyarakat dalam proses Pemilihan Kepala Daerah di tingkat lokal. Dalam sirkulasi elite, konflik bisa muncul dari dalam kelompok itu sendiri maupun antarkelompok pengusaha maupun kelompok tandingan.

Sirkulasi elite menurut Pareto terjadi dalam dua kategori yaitu: Pertama, pergantian terjadi antara kelompok-kelompok yang memerintah sendiri, dan Kedua, pergantian terjadi di antara elite dengan penduduk lainya. Pergantian model kedua ini bisa berupa pemasukan yang terdiri atas dua hal yaitu: (a). Individu-individu dari lapisan yang berbeda kedalam kelompok elite yang sudah ada, dan atau (b). Individu-individu dari lapisan bawah yang membentuk kelompok elite baru dan masuk ke dalam kancah perebutan kekuasaan dengan elit yang sudah ada. Asumsi teori elit mengatakan bahwa dalam setiap masyarakat terbagi dalam dua kategori : 1) Sekelompok kecil manusia yang memiliki kemampuan dan karenanya menduduki posisi untuk memerintah, dan mereka disebut: (a.) Elite yang berkuasa dan (b.) Elite yang tidak berkuasa. 2). Sejumlah besar massa yang ditakdirkan untuk diperintah. (Varma 1975).

Sedangkan Baswedan (2006) memetakan elite politik Indonesia berdasarkan kurun waktu tertentu. Berikut digambarkan dalam tabel. 
Tabel 4. Formasi dan Sirkulasi Rulling Elite Indonesia Versi Anies Baswedan

\begin{tabular}{llll}
\hline \multicolumn{2}{c}{ Fase Pembentukan Elite } & \multicolumn{2}{c}{ Fase Maturitas Elite } \\
\hline $\begin{array}{l}\text { Periode } \\
\text { 1990-an - 1930-an }\end{array}$ & Tren/ Jalur Rekruitmen & Periode Maturitas & Rulling Elite \\
Pendidikan Modern & 1940-an - 1960-an & Intelektual \\
1940-an - 1960-an & Perjuangan Fisik & 1970-an - 1990-an & Angkatan \\
1960-an - 1990-an & Organisasi Massa/Politik & 2000-an - 2020-an & Aktivis \\
1990-an - Sekarang & Pasar/Dunia Bisnis & 2020-an - ? & Enterpreneur/ \\
& & & Bisnisman \\
\hline
\end{tabular}

Sumber: Tabel ini dikembangkan oleh Alfan Alfian berdasarkan opini "Siapakah Rulling Elite Indonesia" karya Anies Baswedan (Kompas, 31 Oktober 2006).

Pembentukan ruling elite Indonesia versi Baswedan (2006) ditentukan atas dasar dua hal, perekrutan anak-anak muda dan tren utama bangsa. Tren utama bangsa ini berubah dari satu masa ke masa berikutnya seiring dengan perjalanan sejarah. Anak-anak muda yang pada masa mudanya terlibat dalam tren utama yang mewarnai bangsa ini kelak akan menjadi aktor-aktor di dalam ruling elite. Di sinilah kerangka Path Dependence (historical institutionalism) jadi relevan dan powerful.

\section{METODE PENELITIAN}

Penelitian ini adalah penelitian deskriptif kualitatif. Menurut Bogdan dan Taylor, penelitian kualitatif adalah penelitian yang menghasilkan data deskriptif berupa katakata tertulis atau secara lisan dari orang-orang dan perilaku yang dapat diamati. (Moleong,2006:4). Sedangkan lokasi penelitian ini dilakukan di kantor DPD I dan DPD II partai Golkar Bangka Belitung. Sementara itu, informan dalam penelitian ini adalah Ketua DPD I Partai Golongan Karya, Ketua KPUD Provinsi Kepulauan Bangka Belitung, Ketua DPD II Partai Golkar, Sekertaris partai, pengurus harian partai dan Elit partai yang dianggap dapat memberikan informasi yang valid dan relevan dengan topik penelitian.

Data penelitian yang dilakukan diperoleh dari: pertama, wawancara, untuk mendapatkan data dan informasi dan ide melalui tanya jawab. Kedua, Observasi, menganalisis langsung dinamika politik di internal partai Golkar Provinsi Kepulauan Bangka Belitung, dan ketiga, Dokumentasi, mengumpulkan dokumen seperti buku harian partai, sejarah partai, hasil perolehan suara partai, peraturan dan kebijakan partai. Untuk menganalisis hasil penelitian yang dilakukan penulis mengunakan unit analisis seperti yang di gampang dalam Hamidi (2005: 75-76) menyatakan bahwa unit analisis adalah 
satuan yang diteliti yang bisa berupa individu, kelompok, benda atau suatu latar peristiwa sosial seperti misalnya aktivitas individu atau kelompok sebagai subjek penelitian.

Dari cara mengungkap unit analisis data dengan menetapkan kriteria responden tersebut, peneliti dengan sendirinya akan memperoleh siapa dan apa yang menjadi subjek penelitiannya. Dalam hal ini peneliti akan mencoba menemukan informan awal yakni orang yang pertama memberi informasi yang memadai ketika peneliti mengawali aktivitas pengumpulan data. Adapun yang menjadi informan awal dari penelitian ini adalah Hendra Apollo selaku ketua DPD I partai Golkar Provinsi Kepulauan Bangka Belitung.

\section{HASIL DAN PEMBAHASAN}

\section{Roots in Society}

Konsep roots in society adalah sebuah pemahaman publik terhadap partai itu sendiri. Oleh karena itu, partai politik harus mampu mencitrakan diri kepada publik yang berorientasi kepada kepercayaan yang tinggi dari publik terhadap partai. Jika dimata publik memiliki citra yang baik dan positif, maka akan berdampak terhadap internal partai, misalnya dalam hal dukungan konstituen dalam pagelaran pesta demokrasi periodik. Namun jika dimata publik partai memiliki citra yang tidak diinginkan, maka konsekuensinya adalah partai akan ditinggalkan oleh publik. Faktanya, banyak sekali partai yang terus berupaya untuk tampil sebagai partai yang pro rakyat. Upaya pencitraan yang dilakukan oleh partai politik dapat implementasikan melalui proses proses politik maupun fenomena bencana alam. Hal ini diharapkan dapat meningkatkan popularitas partai.

\section{Kiprah Partai dalam Masyarakat}

Kiprah partai Golkar di Provinsi Kepulauan Bangka Belitung dalam konteks pemilu, partai Golkar sangat familiar, hal ini ditegaskan melalu perolehan suara yang mengantarkan beberapa elit parti menduduki jabatan anggota DPRD. Kiprah Partai Golkar dimasyarakat diwujudkan melalu kegiatan kegiatan partai, baik itu dilakukan secara kelembagaan dan individu elit dan anggota partai. Selain itu melalui Reses, anggota DPRD dari partai Golkar selalu menyerap aspirasi masyarakat dan melakukan pendekatan persuasif diluar jadwal reses. Melalui diskusi lokal dan pasar murah di moementum momentum juga merupakan strategi partai Golkar meningkatkan eksistensi di masyarakat. Anggota dan Elit partai Golkar bisa memanfatkan kegiatan kegiatan dan momentum dalam meningkatkan eksistensi dan hubungan yang lebih dekat dengan masyarakat. Dalam kegiatan kegiatan keagamaan, elit dan anggota partai selalu hadir ditengah tengah masyarakat. Hal ini merupakan sebuah pencitraan berorientasi kepada eksisntensi partai Golkar Provinsi Kepulauan Bangka Belitung. 
Kiprah Partai dalam Politik Lokal

Partai Golkar Provinsi Kepulauan Bangka Belitung dalam kancah politik lokal menjadi salah satu partai yang tidak bisa dianggap remeh oleh partai lain. Dalam pelaksanaan pesta demokrasi ditingkat lokal baik pemilihan legislatif maupun pemilukada. Partai Golkar adalah suatu partai yang mendapatkan dukungan dari masyarakat. Terbukti, Partai Golkar Provinsi Kepulauan Bangka Belitung berhasil mengantarkan kadernya sebanyak 7 (tujuh) orang di DPRD Provinsi Kepulauan Bangka Belitung pada Pileg tahun 2014. Bahkan salah satunya meraih perolehan suara tertinggi dan menjabat wakil ketua DPRD Provinsi Kepulauan Bangka Belitung. Sedangkan pada level eksekutif partai Golkar berhasil mengantarkan Riza Herdavid (wakil ketua bidang perekonomian) sebagai wakil bupati Bangka Selatan periode 2015-2020. Selain itu sejak partai Golkar Provinsi Kepulauan Bangka Belitung terbentuk telah berhasil mengantarkan Hudarni Rani (ketua Golkar pertama) sebagai Gubernur Bangka Belitung, kemudian dilanjutkan Eko Maulana Ali ( mantan ketua kedua) sebagai Gubernur Bangka Belitung dua periode. Selain itu, Hidayat Arsani ( mantan ketua ketiga ) sebagai wakil Gubernur berpasangan dengan Rustam Effendi sebagai Gubernur. Dengan demikian, partai Golkar Bangka Belitung memiliki cukup kekukuatan di kancah politik lokal dan memiliki citra yang bagus.

Strategi partai melaluimelalui fraksi fraksi di DPRD selalu memperjuangan aspirasi masyarakat Bangka Belitung. Selain itu, anggota DPRD dari partai Golkar selalu merespon cepat isu isu aktual di masyarakat dan selalu mengambil langkah solutif dalam mengatasi permasalahan yang terjadi. Sedangkan dilevel eksekutif kader Golkar selalu merumuskan kebijakan kebijakan yang pro rakyat.

\section{Autonomy}

Otonomi Pengambilan Keputusan

Dalam hal pengambilan keputusan, partai Golkar selalu berpedoman kepada mekanisme partai yang telah di rumuskan bersama. Pertama, dalam pengambilan keputusan, partai Golkar selalu berdasarkan aturan Ad/Art partai. Baik dalam pengambilan kebijakan kebijakan partai dalam perhelatan konstestasi politik ditingkat lokal seperti Pilkada (Pemilihan Kepala Daerah). Kedua, selain kebijakan aturan Ad/Art, partai selalu berpedoman kepada aturan aturan yang dibuat pemerintah dan lembaga penyelanggara pemilu seperti Bawaslu dan KPU. DPD I partai memiliki otoritas dalam menyeleksi seluruh tahapan pilkada untuk seterusnya diberikan ke tingkat yang lebih tinggi kedudukannya.

Kemandirian dalam pengambilan keputusan masih diwarnai dengan kepentingan kepentingan segelintir elit partai. Biasanya intervensi yang dilakukan elit elit partai bisa saja tidak sejalan dengan keinginan dan kehendaki partai itu sendiri. Kepentingan elit ini kemudian bisa saja bermain untuk mengkhendaki kepentingan kepentingan di 
inginkan partai. Intervensi dan campur tangan kepentingan elit dalam pengambilan keputusan menjadi partai tidak independen dalam pengambilan keputusan. Ketelibatan elit ini dikarena mereka sebagai donator dalam kemajuan partai Golkar Provinsi Kepulauan Bangka Belitung. Oleh karena itu, otonomi dalam pengambilan partai tidak sepenuhnya dimiliki partai Golkar. Otonomi partai Golkar tidak lepas dari intervensi internal partai. Persoalan kepentingan dan dominasi elit tidak bisa dihapuskan dalam proses pengambilan keputusan partai.

\section{Peran "Politik Dagang Sapi" dalam Partai}

Rekrutmen kandidat di Pemilihan Gubernur dan wakil Gubernur di internal partai Golkar diwarnai dengan kekuaatan kekuasaan dan uang. "Politik Dagang Sapi" adalah istilah yang disebutkan oleh ketua DPD I. Sikap otoriter yang digunakan Hidayat Arsani sewaktu memimpin partai memberikan dinamika tersendiri di internal partai. Proses dialogis dan mekanisme partai seringkali tidak dipatuhi oleh Hidayat Arsani.

Menjelang Pilgub 2017 di Provinsi Kepulauan Bangka Belitung, suhu politik di internal partai Golkar tidak mengalami perubahan sebagaimana yang terjadi di partai politik lain yang ada di Bangka Belitung. Hal ini dikarenakan Hidayat Arsani tidak melalukan rekrutmen secara terbuka untuk umum yang bersedia mencalonkan diri di partai Golkar. Berikut hasil wawancara dengan Hendra Apollo ketua DPD I partai Golkar Bangka Belitung :

"Dalam proses rektumen kandidat di pilgub, partai Golkar tidak melalukan secara terbuka sesuai dengan mekasnime AD/ART, hal ini karena Hidayat Arsani sewaktu menjabat sebagai ketua sangat otoriter, apabila ada yang membantah akan di pecat dari partai,

Realitas tersebut mengindikasikan bahwa pengaruh klientisme dalam partai masih sangat tinggi. Dimana kader partai seperti Hidayat Arsani tidak didasarkan atas ideologi dan konstitusi partai. Selain itu, otoriterisme kepemimpinan menyebabkan anggota secara luas tidak dilibatkan, sikap pragmatisme ini kemudian menempatkan pengurus partai yang lain hanya sebagai pelengkap struktural.

\section{Kekuatan Organisasi}

Kekuatan organisasi dapat dilihat melalui keutuhan internal organisasi partai Golkar dari level DPP sampai DPD II. Sejauh partai Golkar dibentuk tidak ada gejolak di internal partai. Meskipun ada sedikit kritik dari anggota maupun simpatisan. Hal itu merupakan upaya kader untuk menata kembali partai Golkar sesuai dengan prinsip partai. Selain itu, upaya meredam gejolak yang ada, partai selalu memberdayakan seluruh anggota, melibatkan seluruh anggota disetiap perumusan kebijakan yang ada di DPD I Golkar Bangka Belitung. 
Faksi-faksi yang muncul itu hanya momentum misalnya di pengambilan kebijakan terhadap arah partai kedepan, dan kekecewaan terhadap kebijakan partai. Hal ini senantiasa ditanggapi sebagai bagian dari dinamika politik di internal partai. Secara keseluruhan, faksi-faksi yang muncul tidak menggangu keutuhan organisasi dan harmonisai seluruh kader Golkar.

\section{Sumber Keuangan Partai}

Sejak terbentuknya partai Golkar Provinsi Kepulauan Bangka Belitung delapan belas tahun yang lalu. Dalam upaya menghidupkan roda partai, uang operasional didapatkan melalui sumbangan-sumbangan dari eksternal partai maupun internal partai. Selain itu, sumber keuangan partai didapatkan melalui iuran partai.

Tabel 5. Sumber Keuangan Partai

\begin{tabular}{clc}
\hline No & \multicolumn{1}{c}{ Sumber } & Jumlah \\
\hline 1 & Iuran Partai & $50.000 /$ Bulan \\
2 & Fraksi Golkar & $1.800 /$ suara \\
3 & Sumbangan Simpatisan & 100 jt-200jt \\
\hline
\end{tabular}

\section{Sumber: Diolah oleh penulis}

Meski demikian, tidak semua kader partai Golkar yang menaati seluruh kewajiban iuran yang sudah ditetapkan oleh partai. Kenyataan ini kemudian memunculkan ketidakpedulian kader terhadap masa dengan masa depan partai. Hal ini menyebabkan leluasanya oknum eksternal yang membantu biaya operasional partai mengintervensi kebijakan kebijakan yang dirumuskan oleh partai.

\section{Coherence}

\section{Kekompakan di Internal Partai}

Proses demokratisasi di dalam internal partai Golkar mengalami kemunduran, hal ini disebabkan oleh otoritarisme ketua partai dalam proses penentuan kandidat di Pilgub 2017. Kebijakan yang tidak mengakomodir seluruh masukan dari pengurus setingkat dibawah DPP. Dalam artian, proses pembuatan keputusan dalam hampir semua partai politik dapat disimpulkan tidak bersifat kolektif karena dalam praktek pembuatan keputusan berada pada satu tangan penguasa partai (personalistik) dan/ atau sekelompok kecil elit partai yang sangat loyal kepada sang penguasa (oligarkhi). 
Kenyataan itu menghasilkan konflik di dalam internal partai, sebagian dari pengurus memutuskan untuk keluar dari partai. Menurut hasil wawancara dengan ketua DPD I partai Golkar mengatakan :

"Ada banyak kader yang sesungguhnya tidak sepakat dengan majunya Hidayat Arsani sebagai Gubernur. Namun pengurus DPC tidak memiliki kewenangan untuk mengintervensi pengurus DPD I. harus kita aku sehingga banyak kader yang tidak sejalan di keluarkan dari partai dan mengundurkan diri"

Sikap kritis pengurus dan kader dalam menyikapi kebijakan dan persoalan masalah dinamika di internal menimbulkan sikap antipati terhadap proses pemenangan partai di Pilgub 2017. Ketidakharmonisan ini disampaikan oleh H. Marsidi selaku ketua DPD II Kabupaten Bangka Selatan. Berikut hasil wawancara:

“Bagaimana mau harmonis, kami tidak pernah dilibatkan dalam proses apapun, bahkan ketua DPD II Bangka Barat di pecat oleh ketua lama karena tidak sejalan dengan beliau, kamu ikut saja kebijakan apapun daripada posisi kami tercancam".

Pemecatan secara faksa yang dilakukan Hidayat Arsani menyisakan konflik yang mendalam di internal partai, sehingga kader partai menjadi tidak kompak antara kader dan pengurus harian dan situasi di internal menjadi tidak harmonis dengan calon Gubernur dan Wakil Gubenur.

\section{PENUTUP}

\section{Kesimpulan}

Berdasarkan pembahasan diatas, dapat ditarik kesimpulan bahwa kekalahan calon dari partai Golkar di akibatkan karena institusionalisasi partai politik di internal partai Golkar Provinsi Kepulauan Bangka Belitung belum berjalan dengan maksimal dan baik. Selain itu ada beberapa faktor kekelahan diantaranya sebagai berikut :

Pertama, dalam hal pengambilan kebijakan rekrutmen calon Gubernur dan Wakil Gubernur di pemilihan tahun 2017 masih diwarnai dengan pelanggaran konstitusi partai dalam artian pengurus partai dalam rekrutmen tidak berdasarkan mekanisme aturan AD/ART partai. Pengurus Golkar di level daerah tidak dilibatkan dalam proses penjaringan, seleksi, dan penetapan calon Gubernur ditubuh partai Golkar.

Kedua, adanya "politik dagang sapi" dalam proses rekrutmen mengisyaratkan kecendrungan uang masih sangat kuat dalam mendapatkan rekomendasi dari level pusat dan dukungan dari level pengurus partai di daerah. Selain itu, sikap otoriter Hidayat Arsani yang menyebabkan antipati kader partai yang menyebabkan pengurangan suara dan dukungan dari internal partai itu sendiri. 
Ketiga, adanya pembelotan kader dalam proses pemenangan di Pilgub 2017 di Provinsi Kepulauan Bangka Belitung. Hal ini didasari oleh sikap kritis kader dan pengurus harian partai terhadap kebijakan partai yang mengusung Hidayat Arsani sebagai calon Gubernur. Pembelotan kader dan pengurus ini di asumsikan oleh penulis karena pelembagaan partai yang tidak berjalan maksimal.

\section{Saran}

1. Melaksanakan proses rekrutmen politik dengan memperhatikan mekanisme partai, Ad/art, dan konstitusi partai yang berlaku.

2. Menata lembaga internal partai berdasarakan aturan partai.

3. Melakukan proses kaderidasi bertahap yang berorientasi kepada distribusi ideologi kepada seluruh anggota, kader, pengurus harian partai.

\section{REFERENSI}

Basedau, M \& Stroh, A. (2008). Mearusing Party Institusioalizaton in Developing Countries: A New Research Instrument Applied to 28 African Political Parties, GIGA Research Programme: Legitimacy and Efficiency of Political Systems. Number 69.

Baswedan, A. (2006) “Siapakah Rulling Elite Indonesia” dalam Harian Kompas.

Eristyawan, F. N. (2014). Pelembagaan Partai Kebangkitan Bangsa Studi Kasus Kemerosotan Suara Pada Pemilihan Umum. Jurnal Unair, 2(3).

Harjanto, N. (2011). Politik Kekerabatan dan Institusionalisasi Partai Politik di Indonesia. Analisis CSIS: Politik Dan Kekerabatan Di Indonesia, 40(2), 138-159.

Huntington, SP, \& Nelson, J. (1994). Partisipasi Politik di Negara Berkembang. Jakarta:Rineka Cipta.

Holil, M. (2009) Dinamika Politik Islam Golkar di Era Orde Baru. Tangerang: Gaya Media Pratama.

Imansyah, T. (2012). Regulasi partai politik dalam mewujudkan penguatan peran dan fungsi kelembagaan partai politik. Jurnal Rechts Vinding: Media Pembinaan Hukum Nasional, ,1((3)), 375-395.

Moelong, L. (2006). Metodologi Penelitian Kualitatif, Edisi Revisi. Bandung: Remaja Rosdakarya.

Romli, L. (2016). Reformasi partai politik dan sistem kepartaian di indonesia. Journal Politica, 2(2), 199-220.

Solikhin, A. (2017). Menimbang Pentingnya Desentralisasi Partai Politik di Indonesia. Journal of Governance, 2(1).

Syamsuddin, H. (2016). Demokratisasi Partai dan Dilema Sistem Kepartaian di Indonesia. Jurnal Penelitian Politik, 3(1), 67-76. 
Towar Ikbal Tawakkal, G. (2009). Peran Partai Politik Dalam Mobilisasi Pemilih Studi Kegagalan Parpol Pada Pemilu Legislatif di Kabupaten Demak 2009. (Doctoral Dissertation, UNIVERSITAS DIPONEGORO.

Tandjung, A. (2007). The Golkar Way : Survival Partai Golkar Di Tengah Turbulensi Politik Era Transisi (Jakarta: Gramedia Pustaka Utama.

Varma, SP. (1975). Teori Politik Modern, Jakarta: Raja Grafindo Persada.

Winters, J. (2011) Oligarki, Jakarta: Gramedia Pustakan Utama. 